\title{
Pengaruh Perbandingan Modified Cassava Flour (Mocaf) dan Puree Wortel (Daucus carota L.) Terhadap Karakteristik Cake
}

\section{The Effect of Comparison Modified Cassava Flour (MOCAF) and Carrot Puree (Daucus carota L.) on the Characteristics of Cake}

\author{
Gayatri Ayu Fardiaza ${ }^{1}$, Putu Timur Ina ${ }^{1 *}$, I Desak Putu Kartika Pratiwi ${ }^{1}$ \\ Program Studi Teknologi Pangan, Fakultas Teknologi Pertanian, Universitas Udayana \\ Kampus Bukit Jimbaran, Badung-Bali \\ *Penulis korespondensi: Putu Timur Ina, Email: timurina@unud.ac.id
}

\begin{abstract}
The study aims to determine the effect of comparison mocaf with carrot puree to the characteristics of cake and to find out the best comparison mocaf with carrot puree to produced cake with the best characteristics. The experimental design used in this research was a Completely Randomized Design (CRD) with a comparison of mocaf and carrot puree consisting of 6 treatments namely: 100\%:0\%; 90\%:10\%; 80\%:20\%; 70\%:30\%; 60\%:40\%; 50\%:50\%. The treatment was repeated 3 times so that they were obtained 15 experimental units. The data obtained were analyzed by variance and if the treatment had significant effect then followed by Duncan's Multiple Range Test (DMRT). The comparison of mocaf and carrot puree had a significant effect on water content, ash content, crude fiber, levels of betacarotene, antioxidant activity, hedonic test (color, texture), scoring test (color, flavor, taste, and overall acceptance). Ratio of 50\% mocaf and $50 \%$ carrot puree had the best characteristics with water content $33.24 \%$, ash content $1.24 \%$, crude fiber $9.55 \%$, levels of betacarotene $6.53 \mathrm{mg} / 100 \mathrm{~g}$, antioxidant activity $2.88 \mathrm{mg} / \mathrm{ml}$, color were yellow and liked, pore uniformity were very equal and liked, texture were very soft and liked, aroma, taste and overall acceptance were liked.
\end{abstract}

Keywords: cake, mocaf, carrot puree

\section{PENDAHULUAN}

Cake banyak digemari masyarakat terutama bagi anak-anak sampai usia lanjut karena teksturnya yang lembut, rasa yang enak dan penampilannya yang beragam. Cake biasanya berbentuk adonan panggang berbahan dasar terigu, gula, telur dan lemak (Handayani dan Aminah, 2011). Salah satu bahan utama pada cake yang menjadi kebutuhan masyarakat Indonesia adalah terigu.

Kebutuhan terigu Indonesia terpenuhi dengan impor gandum karena Indonesia bukan negara penghasil gandum, hal ini berdampak pada meningkatnya impor gandum. Menurut data Badan Pusat Statistik, pada tahun 2019 impor gandum sudah mencapai 10.692.978 ton per tahun dan diperkirakan akan meningkat setiap tahunnya (Anonim., 2019). Terigu mengandung protein berupa gluten yang tidak semua orang dapat mengkonsumsi dan mencerna gluten dengan baik seperti penyandang celiac disease atau gangguan saluran pencernaan (Yustisia, 2013). Perlu adanya upaya untuk mengurangi ketergantungan dalam impor gandum dengan menggunakan produk alternatif yang mampu menggantikan terigu. Salah satu produk alternatif yang tidak mengandung gluten yaitu modified cassava flour (mocaf).

Mocaf adalah produk tepung dari singkong (Manihot esculenta Crantz) yang diproses menggunakan prinsip memodifikasi struktur sel 
singkong secara fermentasi, dimana Bakteri Asam Laktat (BAL) mendominasi selama fermentasi tepung singkong ini (Subagio dan Windrati, 2012). Perlakuan fermentasi tersebut dapat menghasilkan tepung dengan tekstur yang lembut, putih, tidak berbau khas singkong, serta memiliki serat yang lebih tinggi dibandingkan dengan terigu. Menurut penelitian Damayanti et al (2014) mocaf sudah bisa dipergunakan $100 \%$ sebagai subtitusi terigu dalam membuat cake dengan keunggulan yakni kandungan kalsium sebesar 10,53 mg/100 g dan serat sebesar 4,34\% yang lebih tinggi jika dibandingkan dengan cake yang dibuat dari terigu yakni kalsium sebesar $6,67 \mathrm{mg} / 100 \mathrm{~g}$ dan serat sebesar 2,86\%. Mocaf tinggi kandungan kalsium dan serat akan tetapi rendah kandungan senyawa bioaktif. Untuk memperkaya nilai fungsional dari cake yang terbuat dari mocaf, dapat ditambahkan bahan lain yang memiliki kandungan senyawa bioaktif. Salah satu komoditi hortikultura yang dapat digunakan adalah wortel.

Pemilihan wortel didasari karena wortel kaya akan betakaroten yaitu sebesar 12.000 SI yang berfungsi sebagai antioksidan yang dapat melindungi sel dari mekanisme oksidasi Low Density Lipoprotein (LDL), penetralisir radikal bebas, sehingga resiko penyakit kardiovaskuler dapat dicegah (Widiatrilupi dan Purwanti, 2019). Selain itu, wortel dapat berfungsi sebagai pewarna makanan alami sehingga cake menjadi berwarna kuning. Penambahan wortel pada cake akan berbentuk puree. Puree merupakan makanan yang biasanya dilembutkan dengan blender. Penggunaan puree bertujuan untuk mempermudah pencampuran bahan-bahan dalam proses pembuatan cake sehingga adonan tidak liat. Menurut penelitian Alfirochah dan Bahar (2014) penambahan puree wortel berpengaruh terhadap warna kerak, warna bagian dalam, dan tingkat kesukaan pancake. Menurut Amdala dan Bahar (2017) interaksi substitusi mocaf dan penambahan puree wortel berpengaruh terhadap mutu organoleptik waffle yang meliputi pori-pori dan tingkat kesukaan. Namun belum diketahui perbandingan mocaf dan puree wortel yang tepat untuk membentuk karakteristik cake yang baik sehingga berdasarkan hal diatas perlu dilakukan penelitian mengenai pengaruh perbandingan mocaf dan puree wortel terhadap karakteristik cake.

\section{METODE PENELITIAN}

\section{Tempat dan Waktu}

Penelitian ini dilaksanakan di Laboratorium Analisis Pangan dan Laboratorium Pengolahan Pangan, Program Studi Teknologi Pangan, Fakultas Teknologi Pertanian, Gedung Agrokompleks Universitas Udayana. Waktu penelitian ini berlangsung dari bulan September sampai bulan Oktober 2020.

\section{Bahan dan Alat}

Bahan yang digunakan dalam penelitian ini adalah wortel segar tipe chantenay dengan warna oranye cerah yang diperoleh dari Pasar Badung Bali, mocaf (Ladang Lima), telur ayam, gula pasir (Gulaku), SP, margarin (Forvita), baking powder (Koepoe Koepoe) yang diperoleh dari toko Fenny Denpasar, aquadest, heksan teknis, $\mathrm{H}_{2} \mathrm{SO}_{4}, \mathrm{NaOH}$, alkohol $96 \%$, aseton, petroleum benzene, $\mathrm{Na}_{2} \mathrm{SO}_{4}$, kloroform, etanol, $\beta$-karoten dan asam linoleat. 
Alat yang digunakan adalah mixer, hand blender, baskom, spatula, loyang, panci kukus, kompor gas, teflon, pisau, parutan buah, oven kue (Kirin), timbangan analitik (Shimadzu ATY224), lumpang, Erlenmeyer (Pyrex), beaker (Pyrex), labu ukur (Pyrex), gelas ukur (Pyrex), labu pemisah (Pyrex), spektrofotometer (Genesys 15s Uv-Vis), kuvet, batang pengaduk, cawan poselin, tabung reaksi (Pyrex), vortex (Maxi mix II), kompor listrik, muffle furnace (Daihan), waterbath (Memmert), pipet tetes, pipet volume, gelas plastik, desikator, kertas saring, kertas saring Whatman 42 , corong plastik, dan aluminium foil (Klinkpak).

\section{Rancangan Penelitian dan Analisa Data}

Penelitian ini menggunakan Rancangan acak lengkap (RAL) dengan perlakuan perbandingan mocaf dan puree wortel terdiri dari 6 taraf, yaitu: $\mathrm{P} 0=$ Mocaf $100 \%:$ Puree wortel $0 \%$ $\mathrm{P} 1=$ Mocaf $90 \%:$ Puree wortel 10\% P2 $=$ Mocaf $80 \%:$ Puree wortel $20 \%$ P3 $=$ Mocaf 70\% : Puree wortel 30\% P4 $=$ Mocaf $60 \%:$ Puree wortel $40 \%$ P5 $=$ Mocaf 50\% : Puree wortel 50\%

Masing-masing perlakuan diulang sebanyak 3 kali sehingga diperoleh 18 unit percobaan. Data yang diperoleh dianalisis menggunakan sidik ragam atau Analysis of Variance (ANOVA). Apabila dari hasil uji tersebut terdapat pengaruh maka dilanjutkan dengan uji Duncan Multiple Range Test (DMRT) (Gomez dan Gomez, 1995).

\section{Pelaksanaan Penelitian}

Tahap pelaksanaan penelitian meliputi dua proses yaitu proses pembuatan puree wortel dan proses pembuatan cake.

\section{Proses Pembuatan Puree Wortel}

Wortel yang dipilih merupakan wortel yang memiliki warna oranye cerah dengan tipe chantenay. Lalu wortel dicuci hingga bersih kemudian dikupas kulitnya. Setelah itu wortel dipotong-potong dengan ketebalan $\pm 0,5 \mathrm{~cm}$ dan dilakukan proses blanching menggunakan metode water blanching dengan suhu $80^{\circ}$ selama 5 menit kemudian dihaluskan dengan hand blender (Azhar et al, 2019 yang dimodifikasi).

\section{Proses Pembuatan Cake}

Telur ayam $120 \mathrm{~g}$ dikocok terlebih dahulu menggunakan mixer hingga berbusa selama 3 menit dengan kecepatan sedang. Kemudian gula pasir $100 \mathrm{~g}$ dimasukkan sedikit demi sedikit hingga berubah warna dan mengembang selama 5 menit. Setelah mengembang, ditambahkan dengan $1,25 \mathrm{~g}$ SP dan terus dikocok hingga adonan mengental selama 5 menit. Selanjutnya kecepatan mixer diturunkan menjadi rendah lalu puree wortel ditambahkan ke dalam adonan sesuai perlakuan $(0 \%, 10 \%, 20 \%, 30 \%, 40 \%, 50 \%)$. Setelah puree wortel tercampur rata, ditambahkan $2 \mathrm{~g}$ baking powder yang sudah dicampur dengan mocaf dan dituangkan sedikit demi sedikit sesuai perlakuan $(100 \%, 90 \%, 80 \%, 70 \%, 60 \%, 50 \%)$ hingga tercampur rata. Adonan ditambahkan dengan $40 \mathrm{~g}$ margarin yang sudah dicairkan terlebih dahulu menggunakan teflon. Adonan dipanggang dalam oven pada suhu $180^{\circ} \mathrm{C}$ selama 40 menit.

\section{Variabel yang diamati}

Variabel yang diamati dalam penelitian ini meliputi kadar air dengan metode pengeringan, kadar abu dengan metode pengabuan kering, kadar serat kasar dengan metode hidrolisis asam basa 
(Sudarmadji et al., 1997), total betakaroten dengan metode spektrofotometri (Nielsen, 1995), aktivitas antioksidan dengan metode betakaroten bleaching (Aznam dan Amanah, 2016), dan sifat sensoris meliputi warna, aroma, tekstur, rasa, penerimaan keseluruhan, keseragaman pori dengan uji hedonik dan uji skoring (warna, tekstur, dan keseragaman pori) (Soekarto, 1985).

\section{HASIL DAN PEMBAHASAN}

\section{Hasil Analisis Bahan Baku}

Nilai hasil analisis kadar air, kadar abu, serat kasar, dan total beta karoten mocaf dan puree wortel dapat dilihat pada Tabel 1.

Tabel 1. Nilai rata-rata kadar air, kadar abu, serat kasar, dan betakaroten mocaf dan puree wortel.

\begin{tabular}{ccc}
\hline Variabel & Mocaf & Puree Wortel \\
\hline Kadar Air (\%) & 12,85 & 88,61 \\
Kadar Abu (\%) & 0,38 & 0,52 \\
Serat Kasar (\%) & 5,08 & 10,54 \\
Betakaroten (mg/100g) & 0,00 & 21,09 \\
\hline
\end{tabular}

\section{Hasil Analisis Kimia Cake}

Nilai rata-rata hasil analisis kadar air, kadar abu dan serat kasar cake dapat dilihat pada Tabel 2 serta total betakaroten dan betakaroten bleaching cake dapat dilihat pada Tabel 3.

\section{Kadar Air}

Hasil sidik ragam menunjukkan bahwa perbandingan mocaf dan puree wortel berpengaruh nyata $(\mathrm{P}<0,05)$ terhadap kadar air cake. Hasil penelitian menunjukkan nilai rata-rata kadar air cake pada semua taraf perlakuan berada pada rentang 24,36\% - 33,24\%. Nilai rata-rata kadar air terendah diperoleh pada P0 (100\% mocaf) sebesar $24,36 \%$ dan nilai rata-rata kadar air tertinggi diperoleh pada P5 (90\% mocaf : 10\% puree wortel) sebesar 33,24\% (Tabel 2). Hal ini disebabkan oleh puree wortel yang memiliki kadar air yang lebih tinggi dibandingkan dengan mocaf. Berdasarkan hasil analisis bahan baku, kandungan kadar air puree wortel yaitu $88,61 \%$ sedangkan kadar air mocaf yaitu $12,85 \%$ (Tabel 1). Nilai rata-rata kadar air pada semua perlakuan telah memenuhi standar
SNI tahun 1995 mengenai cake yaitu maksimal $40 \%$. Hasil ini juga didukung oleh penelitian Yunita et al (2020) mengenai pengaruh perbandingan puree wortel dan terigu terhadap karakteristik roti yang menyatakan bahwa kadar air meningkat seiring dengan meningkatnya penambahan puree wortel, dengan kadar air tertinggi diperoleh pada P5 (50\% puree wortel : $50 \%$ terigu) dengan nilai $19 \%$.

\section{Kadar Abu}

Hasil sidik ragam menunjukkan bahwa perbandingan mocaf dan puree wortel berpengaruh nyata $(\mathrm{P}<0,05)$ terhadap kadar abu cake. Hasil penelitian menunjukkan nilai rata-rata kadar abu cake pada semua taraf perlakuan berada pada rentang $0,98 \%-1,24 \%$. Nilai rata-rata kadar abu terendah diperoleh pada P0 (100\% mocaf) sebesar 0,98\% dan tidak berbeda dengan P1 (90\% mocaf : $10 \%$ puree wortel) dan P2 (80\% mocaf : 20\% puree wortel) sedangkan nilai rata-rata kadar abu tertinggi diperoleh pada P5 (50\% mocaf : 50\% puree wortel) sebesar $1,24 \%$ dan tidak berbeda 
dengan P3 (70\% mocaf : 30\% puree wortel) dan P4 (60\% mocaf : 40\% puree wortel) (Tabel 2). Berdasarkan hasil analisis bahan baku, kandungan kadar abu puree wortel sebesar $0,52 \%$ sedangkan kadar abu mocaf sebesar 0,38\% (Tabel 1). Nilai rata-rata kadar abu pada semua perlakuan telah memenuhi standar SNI tahun 1995 mengenai cake yaitu maksimal 3\%. Hasil ini juga didukung oleh penelitian Jaya dan Yusanti (2018) mengenai formulasi surimi ikan patin dan puree wortel terhadap nugget ikan yang menyatakan bahwa kadar abu meningkat seiring dengan meningkatnya penambahan puree wortel, dengan kadar abu tertinggi diperoleh pada SW4 $(60 \%$ surimi dan $40 \%$ puree wortel) dengan nilai 2,34\%.

Tabel 2. Nilai rata-rata kadar air, kadar abu, dan serat kasar cake

\begin{tabular}{cccc}
\hline Perlakuan (M : W) & Kadar Air (\%) & Kadar Abu (\%) & $\begin{array}{c}\text { Kadar Serat Kasar } \\
\mathbf{( \% )}\end{array}$ \\
\hline P0 (100:0) & $24,36 \pm 1,08 \mathrm{~d}$ & $0,98 \pm 0,07 \mathrm{c}$ & $6,20 \pm 0,16 \mathrm{f}$ \\
P1 (90:10) & $26,83 \pm 0,59 \mathrm{c}$ & $1,00 \pm 0,03 \mathrm{c}$ & $6,65 \pm 0,04 \mathrm{e}$ \\
P2 (80:20) & $28,17 \pm 1,26 \mathrm{c}$ & $1,09 \pm 0,07 \mathrm{bc}$ & $7,21 \pm 0,37 \mathrm{~d}$ \\
P3 (70:30) & $29,80 \pm 0,96 \mathrm{~b}$ & $1,14 \pm 0,11 \mathrm{ab}$ & $8,24 \pm 0,04 \mathrm{c}$ \\
P4 (60:40) & $31,13 \pm 0,76 \mathrm{~b}$ & $1,22 \pm 0,04 \mathrm{a}$ & $8,88 \pm 0,32 \mathrm{~b}$ \\
P5 (50:50) & $33,24 \pm 0,54 \mathrm{a}$ & $1,24 \pm 0,03 \mathrm{a}$ & $9,55 \pm 0,32 \mathrm{a}$ \\
\hline
\end{tabular}

Keterangan: Nilai rata - rata yang diikuti oleh huruf yang berbeda pada kolom yang sama menunjukkan perlakuan berbeda nyata $(\mathrm{P}<0,05)$.

$\mathrm{M}=$ Mocaf

$\mathrm{W}=$ Puree Wortel

Tabel 3. Nilai rata-rata kadar betakaroten dan betakaroten bleaching cake

\begin{tabular}{ccc}
\hline Perlakuan $(\mathbf{M}: \mathbf{W})$ & $\begin{array}{c}\text { Total Betakaroten } \\
(\mathbf{m g} / \mathbf{1 0 0 g})\end{array}$ & $\begin{array}{c}\text { Betakaroten Bleaching } \\
(\mathbf{m g} / \mathbf{m l})\end{array}$ \\
\hline P0 (100:0) & $2,15 \pm 0,23 \mathrm{f}$ & $10,28 \pm 0,28 \mathrm{a}$ \\
P1 (90:10) & $3,02 \pm 0,71 \mathrm{e}$ & $8,42 \pm 0,28 \mathrm{~b}$ \\
P2 (80:20) & $4,23 \pm 0,13 \mathrm{~d}$ & $7,25 \pm 0,22 \mathrm{c}$ \\
P3 (70:30) & $5,03 \pm 0,61 \mathrm{c}$ & $5,58 \pm 0,42 \mathrm{~d}$ \\
P4 (60:40) & $5,81 \pm 0,07 \mathrm{~b}$ & $3,59 \pm 0,24 \mathrm{e}$ \\
P5 (50:50) & $6,53 \pm 0,07 \mathrm{a}$ & $2,88 \pm 0,11 \mathrm{f}$ \\
\hline
\end{tabular}

Keterangan: Nilai rata - rata yang diikuti oleh huruf yang berbeda pada kolom yang sama menunjukkan perlakuan berbeda nyata $(\mathrm{P}<0,05)$.

$\mathrm{M}=$ Mocaf

$\mathrm{W}=$ Puree Wortel

\section{Kadar Serat Kasar}

Hasil sidik ragam menunjukkan bahwa perbandingan mocaf dan puree wortel berpengaruh nyata $(\mathrm{P}<0,05)$ terhadap kadar serat kasar cake.
Hasil penelitian menunjukkan nilai rata-rata kadar serat kasar cake pada semua taraf perlakuan berada pada rentang $6,20 \%-9,55 \%$. Nilai rata-rata kadar serat kasar cake terendah diperoleh pada P0 (100\% 
mocaf) sebesar $6,20 \%$ sedangkan nilai rata-rata kadar serat kasar tertinggi diperoleh pada P5 (50\% mocaf : 50\% puree wortel) sebesar 9,55\% (Tabel 2). Semakin tinggi konsentrasi puree wortel maka kadar serat kasar yang dihasilkan semakin meningkat. Berdasarkan uji bahan baku yang dilakukan, kadar serat kasar puree wortel yaitu 10,54\% sedangkan kadar serat kasar mocaf yaitu $5,08 \%$ (Tabel 1). Semakin tinggi serat kasar yang terkandung maka semakin baik untuk pencernaan. Hasil ini juga didukung oleh penelitian Royani (2019) mengenai pengaruh penambahan pasta wortel pada bakso ikan tuna yang menyatakan bahwa kadar serat kasar meningkat seiring dengan meningkatnya penambahan pasta wortel, dengan kadar serat kasar tertinggi diperoleh pada P5 (penambahan pasta wortel 25\%) dengan nilai $3,11 \%$.

\section{Total Beta karoten}

Hasil sidik ragam menunjukkan bahwa perbandingan mocaf dan puree wortel berpengaruh nyata $(\mathrm{P}<0,05)$ terhadap total betakaroten cake. Hasil penelitian menunjukkan nilai rata-rata total betakaroten cake pada semua taraf perlakuan berada pada rentang $2,15 \mathrm{mg} / 100 \mathrm{~g}-6,53 \mathrm{mg} / 100 \mathrm{~g}$. Nilai rata-rata total betakaroten terendah diperoleh pada P0 (100\% mocaf) sebesar $2,15 \mathrm{mg} / 100 \mathrm{~g}$ dan nilai rata-rata total betakaroten tertinggi diperoleh pada P5 (50\% mocaf : 50\% puree wortel) sebesar $6,53 \mathrm{mg} / 100 \mathrm{~g}$ (Tabel 3). Hubungan antara perbandingan mocaf dan puree wortel dengan total betakaroten dapat dilihat pada Gambar 1.

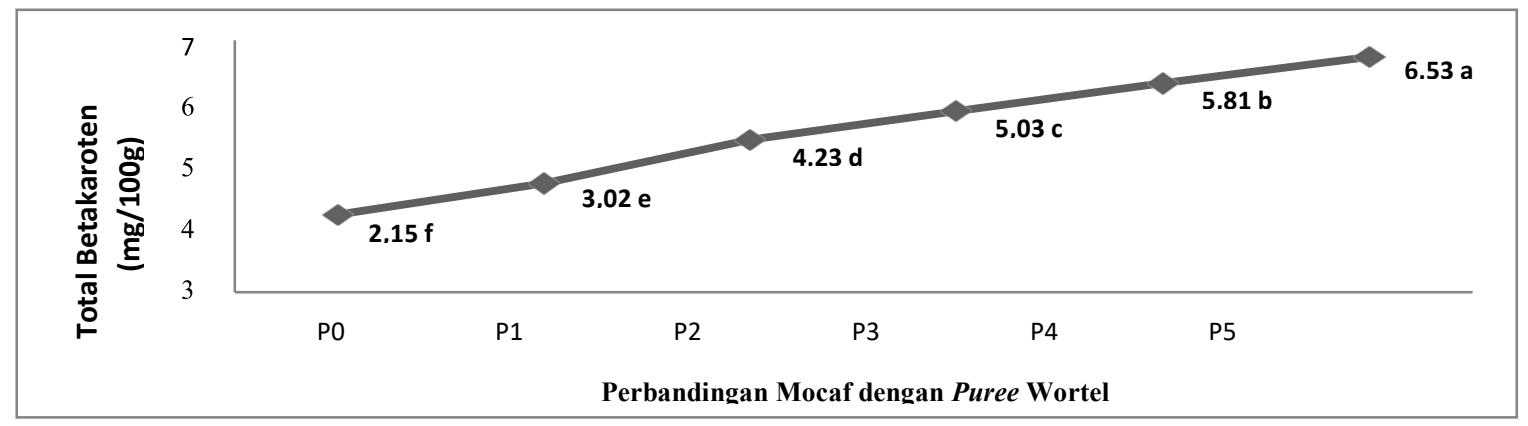

Gambar 1. Hubungan antara perbandingan mocaf dan puree wortel dengan total betakaroten cake

Berdasarkan Gambar 1 dapat dilihat bahwa cake dengan puree wortel yang semakin tinggi menghasilkan total betakaroten yang semakin tinggi. Peningkatan ini disebabkan karena puree wortel memiliki kandungan betakaroten yang tinggi dibandingkan mocaf. Hasil analisis bahan baku menyebutkan total betakaroten puree wortel yaitu $21,09 \%$ sedangkan mocaf $0,00 \%$ (Tabel 1).
Hasil ini sesuai dengan penelitian Royani (2019) mengenai pengaruh penambahan pasta wortel pada bakso ikan tuna yang menyatakan bahwa jumlah pasta wortel yang ditambahkan berpengaruh sangat nyata terhadap total betakaroten bakso ikan tuna, dengan total betakaroten tertinggi diperoleh pada P5 (penambahan pasta wortel 25\%) yaitu 9,64 $\mathrm{mg} / 100 \mathrm{~g}$. 


\section{Aktivitas Antioksidan (Betakaroten Bleaching)}

Hasil sidik ragam menunjukkan bahwa perbandingan mocaf dan puree wortel berpengaruh nyata $(\mathrm{P}<0,05)$ terhadap betakaroten bleaching cake. Hasil penelitian menunjukkan nilai rata-rata betakaroten bleaching cake pada semua taraf perlakuan berada pada rentang $2,88 \mathrm{mg} / \mathrm{ml}-10,28$ $\mathrm{mg} / \mathrm{ml}$. Nilai rata-rata betakaroten bleaching cake terendah diperoleh pada P5 (50\% mocaf : 50\% puree wortel) sebesar $2,88 \mathrm{mg} / \mathrm{ml}$ dan nilai ratarata betakaroten bleaching tertinggi diperoleh pada P0 (100\% mocaf) sebesar 10,28 mg/ml (Tabel 1). Hubungan antara perbandingan mocaf dan puree wortel dengan betakaroten bleaching cake dapat dilihat pada Gambar 2.

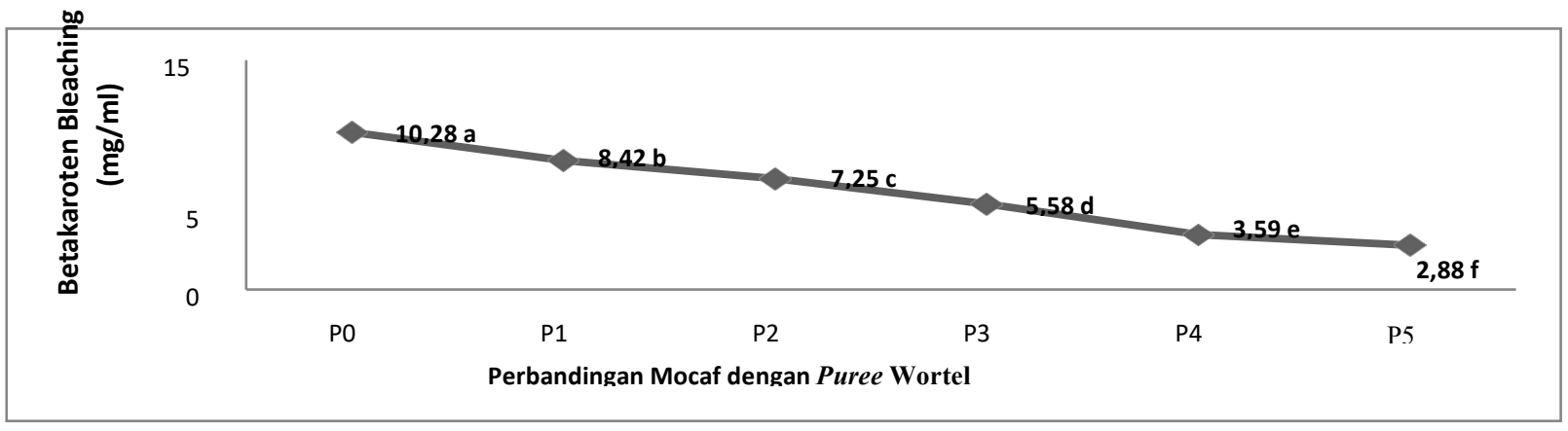

Gambar 2. Hubungan antara perbandingan mocaf dan puree wortel dengan betakaroten bleaching cake

Berdasarkan Gambar 2 dapat dilihat bahwa cake dengan konsentrasi puree wortel yang semakin tinggi menghasilkan betakaroten bleaching cake yang semakin rendah. Semakin rendah nilai betakaroten bleaching cake maka semakin rendah tingkat oksidasi sehingga kemampuan untuk mencegah reaksi oksidasi menjadi lebih tinggi begitu pula sebaliknya. Hal ini disebabkan karena wortel merupakan salah satu jenis sayuran umbi dan dikenal masyarakat sebagai sumber provitamin A dan berfungsi sebagai antioksidan (Bidlack dan Wang, 2000).

\section{Evaluasi Sensoris Cake}

Nilai rata-rata uji hedonik terhadap warna, keseragaman pori, aroma, tekstur, rasa, dan penerimaan keseluruhan cake dapat dilihat pada Tabel 4 dan uji skoring terhadap warna, keseragaman pori, dan tekstur cake dapat dilihat pada Tabel 5.

\section{Warna}

Hasil sidik ragam menunjukkan bahwa perbandingan mocaf dan puree wortel berpengaruh nyata $(\mathrm{P}<0,05)$ terhadap warna (hedonik). Tabel 4 menunjukkan nilai rata-rata warna cake dengan nilai tertinggi diperoleh pada P5 (50\% mocaf : 50\% puree wortel) yaitu 4,57 (sangat suka) dan tidak berbeda dengan P4 (60\% mocaf : 40\% puree wortel) sedangkan perlakuan dengan nilai terendah diperoleh pada P0 (100\% mocaf) yaitu 2,05 (tidak suka) dan tidak berbeda dengan P1 (90\% mocaf : $10 \%$ puree wortel. Hasil sidik ragam menunjukkan bahwa perbandingan mocaf dan puree wortel berpengaruh nyata $(\mathrm{P}<0,05)$ terhadap warna (skoring). Tabel 5 menunjukkan nilai rata-rata 
warna cake dengan nilai tertinggi diperoleh pada P5 (50\% mocaf : 50\% puree wortel) yaitu 3,00 (kuning) dan tidak berbeda dengan P4 (60\% mocaf : 40\% puree wortel), sebaliknya perlakuan dengan nilai terendah diperoleh pada P0 (100\% mocaf) yaitu 1,19 (putih kekuningan) dan tidak berbeda dengan P1 (90\% mocaf : 10\% puree wortel). Hal ini disebabkan karena wortel mengandung betakaroten yang merupakan pigmen warna kuning yang secara alami terdapat didalam produk pangan baik dalam sayuran maupun buah (Rachman, 2004 dalam Mudianto, 2017). Semakin tinggi konsentrasi puree wortel maka akan memberikan warna kuning pada cake. Hasil ini sesuai dengan penelitian Alfirochah dan Bahar (2014) mengenai pengaruh subtitusi mocaf dan penambahan puree wortel terhadap mutu organoleptik pancake yang menyatakan bahwa semakin banyak penambahan puree wortel pada pancake, maka pancake semakin berwarna kuning kejinggaan.

Tabel 4. Nilai rata-rata uji hedonik warna, keseragaman pori, aroma, tekstur, rasa, dan penerimaan keseluruhan cake

\begin{tabular}{|c|c|c|c|c|c|c|}
\hline \multirow{2}{*}{$\begin{array}{c}\text { Perlakuan } \\
(\mathrm{M}: \mathrm{W})\end{array}$} & \multicolumn{6}{|c|}{ Nilai rata - rata uji hedonik } \\
\hline & Warna & $\begin{array}{c}\text { Keseragaman } \\
\text { Pori }\end{array}$ & Aroma & Tekstur & Rasa & $\begin{array}{l}\text { Penerimaan } \\
\text { Keseluruhan }\end{array}$ \\
\hline $\begin{array}{c}\mathrm{P} 0 \\
(100 \%: 0 \%)\end{array}$ & $2,05 \mathrm{~d}$ & $2,05 \mathrm{~d}$ & $2,86 \mathrm{c}$ & $1,81 \mathrm{c}$ & $2,05 \mathrm{c}$ & $2,14 \mathrm{c}$ \\
\hline $\begin{array}{c}\mathrm{P} 1 \\
(90 \%: 10 \%)\end{array}$ & $2,33 \mathrm{~d}$ & $2,38 \mathrm{~d}$ & $3,24 \mathrm{bc}$ & $2,14 \mathrm{c}$ & $2,14 \mathrm{c}$ & $2,33 \mathrm{c}$ \\
\hline $\begin{array}{c}\mathrm{P} 2 \\
(80 \%: 20 \%)\end{array}$ & $3,14 \mathrm{c}$ & $3,05 \mathrm{c}$ & $3,57 \mathrm{~b}$ & $2,95 \mathrm{~b}$ & $2,86 \mathrm{~b}$ & $3,05 \mathrm{~b}$ \\
\hline $\begin{array}{c}\text { P3 } \\
(70 \%: 30 \%)\end{array}$ & $3,62 \mathrm{~b}$ & $3,90 \mathrm{~b}$ & $4,05 \mathrm{a}$ & $4,10 \mathrm{a}$ & $4,10 \mathrm{a}$ & $4,10 \mathrm{a}$ \\
\hline $\begin{array}{c}\mathrm{P} 4 \\
(60 \%: 40 \%)\end{array}$ & $4,29 \mathrm{a}$ & $4,10 \mathrm{ab}$ & $4,19 \mathrm{a}$ & $4,24 \mathrm{a}$ & $4,24 \mathrm{a}$ & $4,52 \mathrm{a}$ \\
\hline $\begin{array}{c}\text { P5 } \\
(50 \%: 50 \%)\end{array}$ & $4,57 \mathrm{a}$ & $4,43 \mathrm{a}$ & $4,38 \mathrm{a}$ & $4,43 \mathrm{a}$ & $4,43 \mathrm{a}$ & $4,29 \mathrm{a}$ \\
\hline
\end{tabular}

Keterangan : Nilai rata - rata yang diikuti oleh huruf yang berbeda pada kolom yang sama menunjukkan perlakuan berbeda nyata $(\mathrm{P}<0,05)$.

$\mathrm{M}=$ Mocaf

$\mathrm{W}=$ Puree Wortel

Kriteria hedonik: 1 (Sangat tidak suka); 2 (Tidak suka); 3 (Biasa); 4 (Suka); 5 (Sangat suka)

\section{Keseragaman Pori}

Hasil sidik ragam menunjukkan bahwa perbandingan mocaf dan puree wortel berpengaruh nyata $(\mathrm{P}<0,05)$ terhadap keseragaman pori (hedonik). Tabel 4 menunjukkan nilai rata-rata keseragaman pori cake dengan nilai tertinggi diperoleh pada P5 (50\% mocaf : 50\% puree wortel) yaitu 4,43 (sangat suka) dan tidak berbeda dengan P4 (60\% mocaf : 40\% puree wortel), sedangkan perlakuan dengan nilai terendah diperoleh pada P0 (100\% mocaf) yaitu 2,05 (tidak suka) dan tidak berbeda dengan P1 (90\% mocaf : 10\% puree 
wortel). Hasil sidik ragam menunjukkan bahwa perbandingan mocaf dan puree wortel berpengaruh nyata $(\mathrm{P}<0,05)$ terhadap keseragaman pori (skoring). Tabel 5 menunjukkan nilai rata-rata keseragaman pori cake dengan nilai tertinggi diperoleh pada P5 (50\% mocaf : 50\% puree wortel) yaitu 2,62 (sangat seragam), sedangkan perlakuan dengan nilai terendah diperoleh pada P0 (100\% mocaf) yaitu 1,19 (tidak seragam) dan tidak berbeda dengan P1 (90\% mocaf : 10\% puree wortel). Panelis lebih menyukai cake pada P5 (50\% mocaf : 50\% puree wortel) dengan kriteria keseragaman porinya sangat seragam. Hal ini disebabkan karena pada P5 (50\% mocaf : 50\% puree wortel) dengan penggunaan puree wortel yang lebih banyak memiliki air yang lebih banyak dibandingkan dengan perlakuan lainnya, sehingga pada saat terkena panas proses gelatinisasi menjadi lebih optimum dan kemampuan untuk menahan $\mathrm{CO}_{2}$ lebih baik.

Tabel 5. Nilai rata - rata uji skoring terhadap warna, keseragaman pori, dan tekstur cake

\begin{tabular}{cccc}
\hline \multirow{2}{*}{ Perlakuan (M:W) } & \multicolumn{3}{c}{ Nilai rata - rata uji skoring } \\
\cline { 2 - 4 } & Warna & Keseragaman Pori & Tekstur \\
\hline P0 (100\%:0\%) & $1,19 \mathrm{~d}$ & $1,19 \mathrm{~d}$ & $1,29 \mathrm{~d}$ \\
P1 (90\%:10\%) & $1,43 \mathrm{~d}$ & $1,24 \mathrm{~d}$ & $1,48 \mathrm{~d}$ \\
P2 (80\%:20\%) & $2,10 \mathrm{c}$ & $1,71 \mathrm{c}$ & $2,57 \mathrm{c}$ \\
P3 (70\%:30\%) & $2,52 \mathrm{~b}$ & $2,14 \mathrm{~b}$ & $3,81 \mathrm{~b}$ \\
P4 (60\%:40\%) & $2,95 \mathrm{a}$ & $2,24 \mathrm{~b}$ & $4,43 \mathrm{a}$ \\
P5 (50\%:50\%) & $3,00 \mathrm{a}$ & $2,62 \mathrm{a}$ & $4,62 \mathrm{a}$ \\
\hline
\end{tabular}

Keterangan : Nilai rata - rata yang diikuti oleh huruf yang berbeda pada kolom yang sama menunjukkan perlakuan berbeda nyata $(\mathrm{P}<0,05)$.

$\mathrm{M}=$ Mocaf

$\mathrm{W}=$ Puree Wortel

Kriteria untuk warna: 1 (Putih kekuningan); 2 (Kuning pucat); 3 (Kuning).

Kriteria untuk keseragaman pori : 1 (Tidak seragam); 2 (Seragam); 3 (Sangat seragam). Kriteia untuk tekstur: 1 (sangat tidak lembut 2 (Tidak lembut); 3 (Biasa); 4 (Lembut); 5 (Sangat lembut)

\section{Aroma}

Hasil sidik ragam menunjukkan bahwa perbandingan mocaf dan puree wortel berpengaruh nyata $(\mathrm{P}<0,05)$ terhadap aroma (hedonik). Tabel 4 menunjukkan nilai rata-rata aroma cake dengan nilai tertinggi diperoleh pada P5 (50\% mocaf : 50\% puree wortel) yaitu 4,38 (suka) dan tidak berbeda dengan P3 (70\% mocaf : 30\% puree wortel) dan P4 (60\% mocaf : $40 \%$ puree wortel), sedangkan perlakuan dengan nilai terendah diperoleh pada $\mathrm{P} 0$ (100\% mocaf) yaitu 2,86 (tidak suka) dan tidak berbeda dengan P1 (90\% mocaf : 10\% puree wortel). Semakin tinggi konsentrasi puree wortel maka semakin tinggi nilai kesukaan panelis terhadap aroma cake. Menurut Winarno (2004), peranan aroma pada makanan sangat penting karena akan menentukan apakah suatu bahan pangan dapat diterima atau tidak oleh konsumen. 


\section{Tekstur}

Hasil sidik ragam menunjukkan bahwa perbandingan mocaf dan puree wortel berpengaruh nyata $(\mathrm{P}<0,05)$ terhadap tekstur (hedonik). Tabel 4 menunjukkan nilai rata-rata tekstur cake nilai tertinggi diperoleh pada P5 (50\% mocaf : 50\% puree wortel) yaitu 4,43 (sangat suka) dan tidak berbeda dengan $\mathrm{P} 4$ (60\% mocaf : 40\% puree wortel) dan P3 (70\% mocaf : 30\% puree wortel), sedangkan perlakuan dengan nilai terendah diperoleh pada P0 (100\% mocaf) yaitu 1,81 (sangat tidak suka) dan tidak berbeda dengan P1 (90\% mocaf : $10 \%$ puree wortel). Hasil sidik ragam menunjukkan bahwa perbandingan mocaf dan puree wortel berpengaruh nyata $(\mathrm{P}<0,05)$ terhadap tekstur (skoring). Tabel 5 menunjukkan nilai ratarata tekstur cake dengan nilai tertinggi diperoleh pada P5 (50\% mocaf : 50\% puree wortel) yaitu 4,62 (sangat lembut) dan tidak berbeda dengan P4 (60\% mocaf : $40 \%$ puree wortel), sedangkan perlakuan dengan nilai terendah diperoleh pada P0 (100\% mocaf) yaitu 1,29 (sangat tidak lembut) dan tidak berbeda dengan P1 (90\% mocaf : 10\% puree wortel). Panelis lebih menyukai cake pada P5 (50\% mocaf : 50\% puree wortel) dengan kriteria tekstur sangat lembut. Hal ini disebabkan karena puree wortel pada P5 (50\% mocaf : 50\% puree wortel) mengandung air yang lebih banyak dibandingkan dengan perlakuan lainnya sehingga proses gelatinisasi menjadi semakin baik. Proses gelatinisasi yang baik akan menyebabkan pori yang dihasilkan semakin seragam, jika cake memiliki pori yang seragam maka tekstur yang dihasilkan semakin lembut.

\section{Rasa}

Hasil sidik ragam menunjukkan bahwa perbandingan mocaf dan puree wortel berpengaruh nyata $(\mathrm{P}<0,05)$ terhadap rasa (hedonik). Tabel 4 menunjukkan nilai rata-rata rasa cake dengan tertinggi diperoleh pada P5 (50\% mocaf : 50\% puree wortel) yaitu 4,43 (suka) dan tidak berbeda dengan P4 (60\% mocaf : 40\% puree wortel) dan P3 (70\% mocaf : 30\% puree wortel), sedangkan perlakuan dengan nilai terendah diperoleh pada P0 (100\% mocaf) yaitu 2,05 (tidak suka) dan tidak berbeda dengan $\mathrm{P} 1$ (90\% mocaf : 10\% puree wortel). Menurut Soekarto (1985), rasa merupakan salah satu indikator untuk menentukan apakah suatu bahan pangan dapat diterima atau tidak oleh konsumen, karena meskipun warna, aroma, dan tekstur makanan baik, akan tetapi jika rasanya tidak enak maka konsumen akan menolak atau tidak menyukai makanan tersebut.

\section{Penerimaan Keseluruhan}

Hasil sidik ragam menunjukkan bahwa perbandingan mocaf dan puree wortel berpengaruh nyata $(\mathrm{P}<0,05)$ terhadap penerimaan keseluruhan (hedonik). Tabel 4 menunjukkan nilai rata-rata penerimaan keseluruhan cake dengan nilai nilai tertinggi diperoleh pada P4 (60\% mocaf : 40\% puree wortel) yaitu 4,52 (suka) dan tidak berbeda dengan P5 (50\% mocaf : 50\% puree wortel) dan P3 (70\% mocaf : 30\% puree wortel), sedangkan perlakuan dengan nilai terendah diperoleh pada P0 (100\% mocaf) yaitu 2,14 (tidak suka) dan tidak berbeda dengan P1 (90\% mocaf : 10\% puree wortel). Penerimaan keseluruhan cake dipengaruhi oleh beberapa faktor seperti warna, keseragaman pori, aroma, tekstur dan rasa. 


\section{KESIMPULAN DAN SARAN}

\section{Kesimpulan}

Berdasarkan hasil penelitian ini dapat disimpulkan bahwa perbandingan mocaf dan puree wortel berpengaruh terhadap kadar air, kadar abu, kadar serat kasar, total betakaroten, aktivitas antioksidan (betakaroten bleaching), warna (uji hedonik dan skoring), keseragaman pori (uji hedonik dan skoring), tekstur (uji hedonik dan skoring), aroma (uji hedonik), rasa (uji hedonik), dan penerimaan keseluruhan (uji hedonik). Perbandingan 50\% mocaf dengan 50\% puree wortel menghasilkan cake dengan karakteristik terbaik yaitu: kadar air 33,23\%, kadar abu 1,24\%, kadar serat kasar 9,54\%, total betakaroten 6,53 $\mathrm{mg} / 100 \mathrm{~g}$, aktivitas antioksidan (betakaroten bleaching) $2,88 \mathrm{mg} / \mathrm{ml}$, warna kuning dan disukai, keseragaman pori sangat seragam dan disukai, tekstur sangat lembut dan disukai, aroma, rasa dan penerimaan keseluruhan disukai.

\section{Saran}

Berdasarkan hasil penelitian disarankan untuk menggunakan perbandingan mocaf $50 \%$ dan puree wortel $50 \%$ dalam pembuatan cake mocaf.

\section{DAFTAR PUSTAKA}

Alfirochah, N. dan A. Bahar. 2014. Pengaruh substitusi tepung mocaf (modified cassava flour) dan penambahan puree wortel (Daucus carota L.) terhadap mutu organoleptik pancake. Jurnal Pendidikan Tata Boga Universitas Negeri Surabaya. 3 (1) : 250-261

Amdala I. P, H. dan A. Bahar. 2017. Pengaruh subtitusi tepung mocaf (modified cassava flour) dan penambahan puree wortel (Daucus carota L.) terhadap sifat organoleptik waffle. Jurnal Fakultas Teknik Universitas Negeri Surabaya. 5 (1) : 87-96.
Anonimus. 2019. Impor Biji Gandum dan Meslin menurut Negara Asal Utama, 2010-2019. Badan Pusat Statistik: Jakarta. https://www.bps.go.id/statictable/2019/02/14/2 016/impor-biji-gandum-dan-meslin-menurutnegara-asal-utama-2010-2019.html. Diakses pada tanggal 12 Desember 2020.

Azhar, A., Y. Rahmawati., A. Mahmudatussa'adah. 2019. Chiffon carrot cake: inovasi cake dengan fortifikasi betakaroten dari wortel dan preferensi konsumen. Jurnal Media Pendidikan, Gizi dan Kuliner Universitas Pendidikan Indonesia. 8 (1).

Aznam, N. dan I. Amanah. 2016. Penentuan kadar total fenol dan uji aktivitas antioksidan kombinasi ekstrak sarang semut (Myrmecodia pendens Merr. \& L.M. Perry) dan ekstrak kencur (Kaempferia galanga Linn.) dengan metode $\beta$ carotene bleaching. Jurnal Kimia Dasar. 21 (3) : $1-9$

Bidlack, W. R dan W. Wang. 2000. Designing Functional Foods to Enchance Health. Blackie Academic \& Professional, London.

Damayanti, D. A., W. Wahyuni., M. Wena. 2014. Kajian kadar serat, kalsium, protein, dan sifat organoleptik chiffon cake berbahan mocaf sebagai alternatif pengganti terigu. Jurnal Teknologi dan Kejuruan. 37 (1) : 73-82

Gomez, K. A. dan A. A. Gomez. 1995. Prosedur Statistik Untuk Penelitian Pertanian. UI Press, Jakarta.

Handayani, R. dan Aminah, S. 2011. Variasi substitusi rumput laut terhadap kadar serat dan mutu organoleptik cake rumput laut (Euchema cottonii). Jurnal Pangan dan Gizi.

Jaya, F. M. dan I. A. Yusanti. 2018. Formulasi surimi ikan patin dan puree wortel yang berbeda terhadap mutu proksimat nugget ikan. Jurnal Enggano 3 (1): 1-9.

Mudianto, S. A. 2017. Pengaruh substitusi tepung mocaf (modified cassava flour) dan penambahan puree wortel (Daucus carota L.) terhadap sifat organoleptik jenang. E- journal Boga Universitas Negeri Surabaya. 5 (1) : 97 - 104.

Nielsen, S. 1995. Introduction to The Chemical Analysis of Food. Chapman and Hall, New York USA.

Ratna. 2019. Resep Cake Biasa. https://cookpad.com/id/resep/2033025-cakebiasa. Diakses pada tanggal 2 Desember 2019.

Royani, I. 2019. Pengaruh Penambahan Pasta Wortel (Daucus carota L.) Pada Bakso Ikan Tuna (Thunnus Sp.) Sebagai Pangan Fungsional. Skripsi. Program Studi Ilmu dan Teknologi Pangan Universitas Udayana.

Soekarto, S. T. 1985. Penilaian Organoleptik untuk 
Industri Pangan dan Hasil Pertanian. Bhratara Karya Aksara, Jakarta.

Subagio, A. dan W. S. Windrati. 2012. Pengaruh komposisi mocaf (modified cassava flour) dan tepung beras pada karakteristik beras cerdas. Jurnal Pangan, 21 (1) : 29-38.

Sudarmadji, S., B. Haryono dan Suhardi. 1997. Prosedur Analisa Untuk Bahan Makanan dan Pertanian Edisi Keempat. Liberty, Yogyakarta.

Widiatrilupi, R. M. M. V. dan A. S. Purwanti. 2019. Pemberian jus wortel berpengaruh terhadap tekanan darah pada ibu hamil trimester iii dengan preeclampsia ringan. Jurnal Penelitian
Kesehatan, 6 (2) : 57-62.

Winarno, F. G. 2004. Kimia Pangan dan Gizi. Cetakan Keenam. PT Gramedia Pustaka Utama: Jakarta.

Yunita, N., I. M. Sugitha., I. G. A. Ekawati. 2020. Pengaruh perbandingan puree wortel (Daucus carota L.) dan terigu terhadap karakteristik roti tawar. Jurnal Itepa. 9 (2): 193-201.

Yustisia, R. 2013. Pengaruh penambahan telur terhadap kadar protein, serat, tingkat kekenyalan dan penerimaan mie basah bebas gluten berbahan baku tepung komposit. Journal of Nutrition College. 2 (4) : 697-7 